\title{
ASSESSMENT OF ECONOMIC LOSSES IN CROPS DUE TO INSECTS
}

\author{
A. D. LOWE
}

Entomology Division, D.S.I.R., Lincoln

Summary

The desire that research workers in New Zealand will produce the type of information required for refined rationalisation of pest control measures in crops seems doomed by the current emphasis on long-term basic research and preventive use of chemicals. The degree of sophistication possible in the case of the wheat crop, where such information is available, is demonstrated by the erection of a cost-benefit model for three levels of yield. Some degree of conflict exists between measures aimed at enhancing profitability in a single crop and longer term community interests such as conservation of beneficial insects.

\section{INTRODUCTION}

For some years the hope has been expressed among those involved in pest control that research activities in this field would produce accurate estimates of pest damage, thus enabling pest control operations to be seen in better perspective. Economic estimates do not appear to be the responsibility of any particular branch of science, but thought has recently been given to this question in relation to field crops, and some of the conclusions form the basis of this paper.

\section{CROPS}

Table 1 lists the areas of crops grown in New Zealand, and gives the total yield of the main field crops, insofar as verifiable figures are published. Crops for hay, and seed crops from lucerne and pasture are included for comparison of acreages.

TABLE 1: FIELD CROPS IN NEW ZEALAND

\begin{tabular}{lcc}
\hline Crop & $\begin{array}{c}\text { Area } \\
\text { hectares (000) }\end{array}$ & $\begin{array}{c}\text { Yield } \\
\text { tonnes (000) }\end{array}$ \\
\hline Brassicas & 227 & N.A. \\
Cereals $\quad$ Including maize & 228 & 682 \\
Peas (threshing) & 239 & 737 \\
Potatoes & 25 & 41 \\
Process crops & 10 & 246 \\
Grasses, clovers, & 10 & N.A. \\
lucerne for hay $\quad$ for seed & 570 & \\
\hline
\end{tabular}

Source of information for whole table: N.Z. Yearbook (1972)

(figures for 1969-70 season).

\section{PESTS}

Most pests affecting these crops are quite well-known, and the type of damage and period of insect attack are defined clearly enough for 


\section{Economics of Weeds and Pests}

recognition by both growers and advisers. Most are single-insect attack, with the exception of insects attacking seedling brassicas, and the aphidvirus complex in this crop. Where more than one insect is involved, as in attack by both aphids and caterpillars (again in brassicas), both problems are clearly recognisable on inspection.

\section{ECONOMICS}

Brassicas: Any attempt to rationalise pest control as a cost benefit exercise for crops, can never lead to generalisation in the brassica crop. This crop stands alone as the crop normally marked for on-the-farm consumption. Its economic value not only depends on season and stocking rate, but also on such intangibles as the economics of utilisation on each property.

The question of insect control in this crop can be solved largely by growing resistant lines of brassicas now readily available. These have been bred at Lincoln for New Zealand conditions, and will produce excellent crops in most parts of the country. The value of a good brassica crop either for lamb fattening or for winter utilisation should not be underestimated. If the alternative is under-feeding of animals or selling of stock of $\$ 100-200$ per hectare might well be a low estimate of worth. Such a figure puts the cost of insect control \$8-20 per hectare for most organo-phosphate materials likely to be used) into reasonable perspective. Where difficulty in establishing brassicas is a problem due to insects, or where aphid or caterpillar attack is heavy enough to justify the application of chemicals, a single application of a chemical would appear to be a relatively inexpensive matter, and more than one application may be justified, especially if treatment can utilise existing farm machinery and labour.

Similar principles apply to other crops such as hay, destined for on-farm utilisation, and probably represent the best estimate that can be achieved in cost-benefit procedures for pest control in such crops.

Wheat: Most other field crops are sold off the farm for a cash return and are therefore much more amenable to cost-benefit calculations. Beside the costs and yields from crop production, the exercise calls for figures covering costs for pest control and likely levels of damage for the various pests, expressed in percentage or actual reduction in yield.

Wheat is at present the only such crop for which this information is available, and an attempt has been made in Fig. 1 to build a costbenefit model covering three levels of yield and the estimates of net gain available under various circumstances, by the application of a pesticide. Three pests affect the crop, and for all of these a reasonable level of estimated yield reduction has been established. These are: cereal aphid (Rhopalosiphum padi) survey by Smith (1963); grain aphid (Macrosiphum miscanthi) experimental evidence by Sanderson \& Mulholland (1969); and army caterpillar, results of survey of damage by this insect at harvest (Lowe, unpub.)

Utilising the whole of the information available, Fig. 1, whatever its limitations, offers for this crop a rationalisation of pest control procedures which can be compared with farmers' other costs (Davies, 1974), with potential profits, and likely benefits from treatment.

Other Crops: Such information is not fully available for the other crops listed in Table 1, the main gap being in level of yield damage likely to be inflicted by individual pests.

It has long been debated as to whether such information is necessary to the rationalisation of pest control procedures, though it is generally acknowledged that it would be helpful and more convincing than recognition of general principles. Way (1972) pointed out that much of today's more fundamental entomological research is concerned with erection of 


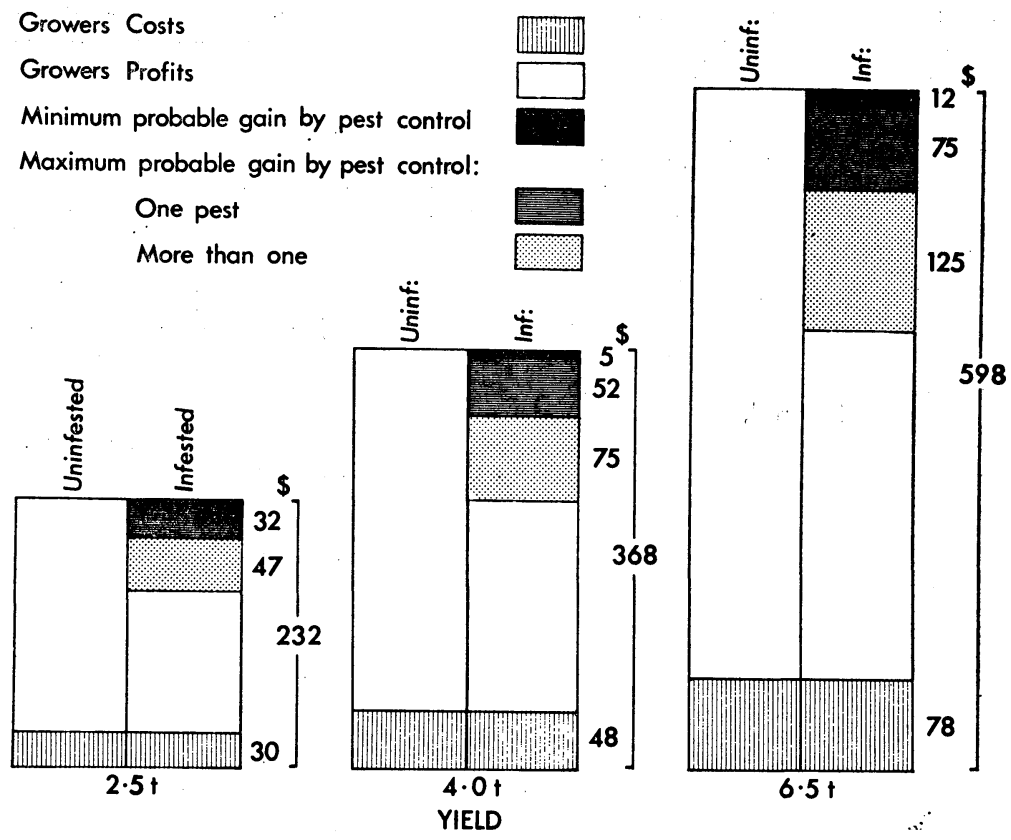

Fig. 1: Cost-benefit model for pest control (3 pests) in wheat (3 levels of yield), showing minimum and maximum net probable gain from single treatment $(\$ 8 / \mathrm{ha})$ with an organophosphorous insecticide, for control of one or more pests. 1974 price of wheat $\$ 92 /$ t. Production costs after Davies (1974). All figures are per hectare.

models that lead to a better understanding of the interactions of the soil-plant-insect system, and are not necessarily aimed directly at pest control. Nevertheless, he said, most persons involved in questions of reduction of damage can erect readily a "mental model" from existing information containing a wide margin of error, and, allowing for this, offer rational, practical advice on pest treatment.

It is possible that such "mental models" are adequate for their purpose, and it is certain that we in New Zealand appear unlikely to replace such a procedure for most crops for some time.

\section{NON-CHEMICAL PEST CONTROL}

Cost-benefit models in such procedures as integrated pest control, avoidance techniques (altered sowing date - wheat - see Lowe, 1973), inundation (e.g. with a natural enemy, see Corbet, 1972), or use of resistant plants (e.g. brassicas, as above), are probably impossible to produce. In such cases, we may never achieve any reliable decision-making guide, except by long experience of results.

\section{CONCLUSIONS}

(1) Any attempt to rationalise pest control procedures in New Zealand field crops at present is hampered by a lack of information on the level of yield damage inflicted by most pests, rather than by lack of knowledge of the pests or their biology. Such information is frequently 
available from well-replicated chemical control experiments for single pests which have already inflicted damage. Current emphasis on use of chemicals to prevent damage does not give rise normally to such information.

A further point to be noted is that some practices such as the use of systematic granules at planting in an attempt to prevent early virus infection of the potato crop by controlling the vector, are acknowledged as fully-effective in controlling an insect problem (Rough \& Close, 1965), without any critical economic evaluation of the system ever having been made. Over several seasons, growers construct their own "mental model" from the results achieved. Such models conclude that the actual cost of insecticidal inputs is exceeded by the benefits accruing from increased yield and the sale or retention of virus-free seed. These however, are the short term accountable factors, while long-term unaccountable factors are ignored.

(2) Much current research is aimed at the long-term goal of understanding biological svstems rather than at the production of information allowing sophisticated calculations on pest control procedures. There seems little present hope for the production of this tvpe of information, unless the task is undertaken by advisory staff, including those employed by commercial organisations.

(3) Corbet (1972) has pointed out that there is inevitably some conflict in pest control operations between the short-term goal of growing a crop to produce a profit over one season, and the long-term goals essential to alleviation of pest problems (e.g. conservation of beneficial insects). The individual grower considering his paddock only as the entity for pest control, may undertake measures not in the best interests of the region or the nation. It is possible that there is no solution to this problem in a so-called "free" society.

(4) Spheres of responsibility for the production and dissemination of pest control procedures in New Zealand appear to be ill-defined, with the exception of the control over the sale of chemicals clearly defined by law as the responsibility of the Agricultural Chemicals Board, and in some respects of the Health Department.

\section{REFERENCES}

Corbet, P. S., 1972. Application, feasibility, and prospects of integrated control. In Insects: studies in population management. Geier, P. W., Clark, L. R., Anderson, D. V., and Nix, H. A. (Ed.) Ecol. Soc. Aust. (memoirs 1): Canberra: 185-95.

Davies, D. J., 1974. Christchurch "Press" 29/3/74. Computations based on Farm Budget Manual Pt. 2, Financial. N. G. Gow (Ed.) Lincoln College Department of Farm Management and Rural Valuation (Lincoln). 1973.

Lowe, A. D., 1973. Aphid biology in New Zealand. In Perspectives in Aphid Biology. A. D. Lowe (Ed.) Entom. Soc. of New Zealand (Inlc.) Auckland: 7-19.

Rough, B. F. A. and Close, R. C., 1965. Use of disulfoton on potatoes. Proc. 18th N.Z. Weed \& Pest Control Conf.: 188-96.

Sanderson, F. R. and Mulholland, R. I., 1969. Effect of the grain aphid on yield and quality of wheat. Proc. 20th N.Z. Weed E Pest Control Conf.: 227-35.

Smith, H. C., 1963. Control of barley yellow dwarf virus in cereals. N.Z. J. Agric. Res. 6: 229-44.

Way, M. J., 1972. Objectives, method, and scope of integrated control. In Insects: Studies in population management. Gier, P. W., Clark, L. R., Anderson, D. J., and Nix, H. A. (Ed.) Ecol. Soc. Aust. (memoirs 1): Canberra. 137-52.

Proc. 27th N.Z. Weed and Pest Control Conf. 